Article

\title{
Improving Horse Welfare and Environmental Sustainability in Horse Husbandry: Linkage between Turnout and Nitrogen Surplus
}

\author{
Miriam Baumgartner ${ }^{1, *} \oplus$, Sandra Kuhnke ${ }^{2}$, Kurt-Jürgen Hülsbergen ${ }^{1}$, Michael H. Erhard ${ }^{3}$ and \\ Margit H. Zeitler-Feicht ${ }^{1}$ \\ 1 TUM School of Life Sciences, Technical University of Munich, 85354 Freising, Germany; \\ huelsbergen@wzw.tum.de (K.-J.H.); zeitler-feicht@wzw.tum.de (M.H.Z.-F.) \\ 2 Chamber of Agriculture in North-Rhine Westphalia, Department 71 Animal Husbandry and Animal Breeding \\ Legislation, 59505 Bad Sassendorf, Germany; sandra.kuhnke@lwk.nrw.de \\ 3 Faculty of Veterinary Medicine, Ludwig-Maximilians-University Munich, 80539 Munich, Germany; \\ m.erhard@tierhyg.vetmed.uni-muenchen.de \\ * Correspondence: m.baumgartner@tum.de
}

check for updates

Citation: Baumgartner, M.; Kuhnke, S.; Hülsbergen, K.-J.; Erhard, M.H.; Zeitler-Feicht, M.H. Improving Horse Welfare and Environmental Sustainability in Horse Husbandry: Linkage between Turnout and Nitrogen Surplus. Sustainability 2021, 13, 8991. https://doi.org/10.3390/ su13168991

Academic Editor: Harry Blokhuis

Received: 27 March 2021

Accepted: 4 August 2021

Published: 11 August 2021

Publisher's Note: MDPI stays neutral with regard to jurisdictional claims in published maps and institutional affiliations.

Copyright: (c) 2021 by the authors. Licensee MDPI, Basel, Switzerland. This article is an open access article distributed under the terms and conditions of the Creative Commons Attribution (CC BY) license (https:// creativecommons.org/licenses/by/ $4.0 /)$.

\begin{abstract}
A scientific consultation tool is currently being developed in Germany to assess, analyze, and improve animal welfare on site and simultaneously consider aspects of environmental sustainability in horse husbandry in order to contribute to a resource-conserving and responsible handling of natural resources and the welfare of living beings. To date, no study has assessed to what extent species-appropriate free-range locomotion possibilities are implemented on horse farms and to what extent turnout areas are affected by unwanted nutrient inputs from horse excretions. Using the indicators "species-appropriate turnout" (hereafter: "turnout") and "unwanted nitrogen inputs in water bodies" (based on "nitrogen surplus"), we exemplarily examine animal- and environmentally relevant aspects of horse husbandry. We conducted 88 assessments on 46 horse farms ( $n=2220$ horses) to test literature-based indicators of animal welfare and environmental sustainability. We found that the indicator "nitrogen surplus," used to assess an aspect of environmental sustainability, was mostly a problem in the wintertime (summertime $=-4.24$, range: $-109.27-58.97$; wintertime: mean: 12.01, range: $-35.19-468.00$ nitrogen surplus per hectare, $n=44$ farms, $p<0.001$ ), when the horses had a reduced space allowance for free locomotion. On most farms, "turnout" was provided daily for several hours, but in many of the single housing systems, not all horses had the possibility for free locomotion $(24.1 \pm 20.4 \%$ of horses per farm), which is unacceptable in terms of animal welfare. Husbandry systems with a large enough space allowance for turnout ( $\geq 200 \mathrm{~m}^{2}$ per horse) were found to be measures with a valuable synergetic effect, providing a resource which is an opportunity both for an environmentally sustainable and welfare-friendly horse husbandry. Demanuring remarkably decreased the nitrogen surplus $(p<0.001)$. Hence, based on the study, we recommend to daily demanure the pasture or paddock if the space allowance is less than $200 \mathrm{~m}^{2}$ per horse. In conclusion, regarding animal welfare, group housing is favorable, but regarding a site-specific environmentally friendly or even biodiversity-enhancing management, space allowance per horse is a crucial factor rather than the type of housing system. The two selected exemplary indictors demonstrate the need for a holistic and comprehensive decision support system that considers the linkage between horse welfare and environmental sustainability in order to assist peoples' decision-making with horses under their care.
\end{abstract}

Keywords: sustainable livestock; welfare assessment system; positive welfare; welfare indicator; space allowance; single housing; group housing; horse farm management; horse yards 


\section{Introduction}

\subsection{Relevance and Linkage of Horse Welfare and Environmental Effects in Horse Husbandry}

Aspects of environmental sustainability and animal welfare play an important role in the social acceptance of farm animal and horse husbandry [1]. According to a survey conducted by the "German Equestrian Federation" (Deutsche Reiterliche Vereinigung e. V.)the worldwide largest equestrian association-approx. $70 \%$ of the more than 21,000 respondents see a substantial need for improvement in horse husbandry and ask for a more thorough control of husbandry conditions for horses [2]. Considering farm animal welfare from a consumers perspective, outdoor access to pasture ranks first [3]. Horseman et al. [4] and Dalla Costa et al. [5] found that one of the biggest animal welfare problems in horse husbandry is long periods of confinement, i.e., stabling for $24 \mathrm{~h}$ a day. Beyond these findings, limited data are available on the welfare of European horses [5]. Furthermore, numerous scientific studies on diseases and behavioral disorders have demonstrated severe shortcomings in horse husbandry, inter alia a lack of turnout [6-9]. A uniform assessment and animal-welfare-compliant optimization of horse husbandry is thus considered much needed.

Regarding aspects of environmental sustainability, the species-typical selective feeding behavior of horses has a positive effect on the plant diversity on pastures. Thus, according to Schmitz and Isselstein [10], the biodiversity on horse pastures, depending on land use and management, can considerably exceed that on cattle pastures. Furthermore, horse pastures as compared with cattle pastures are managed less intensively, because grasses of high energy density are rather unwanted for (non-competing) leisure horses to avoid obesity or nutritionally induced laminitis. Therefore, horse pastures offer a high potential for species richness, notably fostering indicator species for a "high nature value" [10]. However, regarding other sustainability criteria, considerable levels of pollution, emissions, and also damage to soil structure and vegetation can arise on horse pastures. Conflicting goals, as well as synergetic effects, between animal welfare and sustainability aspects are therefore possible.

\subsection{Environmental Relevance of Nitrogen Surplus}

The protection of the natural resource water from harmful nutrient inputs is a key point in the sustainable agricultural use of the planet (Goal 15.1: conservation of freshwater ecosystems [11]). One of the great environmentally relevant challenges of horse keeping is nitrogen surplus [12]. Especially peri-urban horse farms are prone to an elevated risk of unwanted nutrient inputs because the pasture space allowance is often limited $[13,14]$. A small pasture space allowance for horses increases the risk that sparsely vegetated areas develop due to browsing damage and trampling by the horses $[12,15,16]$. Under these circumstances, the excretions of the horses can lead to increased nitrogen inputs in the soil and to correspondingly high nitrogen emissions. The risk of unwanted nutrient losses (nitrogen, phosphorous) into ground and surface waters exists especially in sparsely vegetated areas, where the lack of nitrogen output from horses' excretions by plants can lead to excessive nutrient inputs in the soil and consequently to nitrate $\left(\mathrm{NO}_{3}{ }^{-}\right)$runoff into water bodies $[15,16]$. This course of events has been shown on sparsely vegetated areas used all year for horses [12]. In Germany, horses are kept to a great extent near cities (52\% of the horse farms operated by equine associations and $42 \%$ of the commercial horse farms are in urban or peri-urban areas [17]). Throughout Europe, peri-urban horse husbandry keeps gaining in importance [13,14]. Thus, horse farms of limited area are not uncommon.

In view of public health, regulatory standards exist for the nitrate content in drinkable water. In the EU, the upper threshold for nitrate $\left(\mathrm{NO}_{3}{ }^{-}\right)$is $50 \mathrm{mg} / \mathrm{L}$ of water (ground water and surface freshwater [18]). However, a Danish study showed a relationship between nitrate content and risk of colorectal cancer in humans at concentrations markedly below this threshold, suggesting that the current standard is set too high [19]. Nitrogen is essential for life and has many functions in natural ecosystems. Plants need nitrogen, inter alia, for protein synthesis, and the proteins in turn serve as macronutrients for 
animals. Intensive plant cultivation with excessive fertilization, as well as intensive farm animal husbandry and excessive stocking density, can disrupt this balance. The resulting nutrient accumulations lead to increased greenhouse gas emissions especially in the form of nitrous oxide $\left(\mathrm{N}_{2} \mathrm{O}\right)$ and to the pollution of ground and surface waters with nitrate [20]. Depending on precipitation and soil quality (water absorption capacity), a nitrogen balance (maximal allowed nitrogen surplus = nitrogen input -nitrogen uptake by cultivated plants) of $20 \mathrm{~kg}$ nitrogen per hectare and year can cause elution of $50 \mathrm{mg}$ nitrate per liter of water; therefore, this value was set as the upper threshold in an Austrian directive on regulatory water protection [21]. This value also is an important parameter for horse turnout areas. The German directive on fertilization (as of 2017) helps implement the European Directive 91/676/EWG on the protection of water bodies from agricultural nitrate pollution [22]. It sets the upper threshold of the nitrogen balance, calculated as the average of all agriculturally used areas on a farm, to $50 \mathrm{~kg}$ nitrogen per hectare and year, which is higher than in the Austrian directive. The nitrogen surplus of the area-based nitrogen balance is considered one of the most meaningful agro-environmental indicators; it shows the potential for environmentally relevant nitrogen losses, such as ammonia, nitrous oxide, and nitrate losses [23].

\subsection{Animal Welfare Assessment with a Focus on Horses}

The concept of welfare is based on Broom [24], who defined that "the welfare of an individual is its state as regards its attempts to cope with its environment." This definition includes an individual's feelings, health, and mechanisms for coping. In terms of a One Health, One Welfare approach that considers today's intertwined global challenges of climate change, biodiversity reduction, and sustainability issues, the relations between humans and domesticated animals and their welfare should be viewed in an environmental context [25]. Therefore, the herein presented project aims at combining aspects of environmental sustainability with aspects of animal welfare. The European Animal Welfare Indicators (AWIN) Project $[5,26,27]$ developed a protocol for assessing animal welfare in horse husbandry that is based on valid, scientifically tested indicators. However, this protocol does not include sustainability aspects and allows no comprehensive risk assessment of the husbandry conditions in which the animal lives because the indicators are mostly animal based. Animal based means that health and behavioral signs of the horses itself are taken into account, not the conditions in which they live in. Furthermore, it focuses on single housing of horses, which means group housing of horses is neglected. Finally, scientific studies from Sweden showed that managers of horse farms would welcome a feedback system providing them with benchmarks and advice on improvements rather than just the welfare state of the horses [28,29].

\subsection{Turnout as a Welfare Concern}

On the one hand, lack of free locomotion leads to musculoskeletal damage and compromises self-purification mechanisms in the respiratory tract $[30,31]$. For example, foals with little daily turnout (less than $4 \mathrm{~h}$ ) in the first four months of life are more prone to develop osteochondrosis than foals with longer turnout duration [32]. On the other hand, horses have the innate need or motivation (classically referred to as proximate control of behavior) for locomotion [33]. Metz-Göckel [34] defined a "need" as experiencing a lack and a feeling associated with wanting to "remedy" the lack. If an animal expects an outcome and can achieve it through behavioral output, the original motivation declines and the achievement is perceived as positive. The outcome creates the positive affective state of "liking." If an outcome cannot be achieved, needs satisfaction is not possible and frustration arises. Chronic frustration is the main cause of stereotypic behaviors $[33,35,36]$. The latter are a strong indicator of suffering due to inappropriate husbandry conditions. Stereotypic behaviors due to insufficient turnout have previously been described in the literature. For instance, Hockenhull und Creighton [37] discovered a high prevalence of housing-related behavioral problems in leisure horses and a trend toward year-round stabling. The study 
revealed restrictions in turnout possibilities, indicating that restricted turnout might have welfare costs; for example, stabling horses for 21-24 h a day was associated with abnormal oral behavior. Keeping horses for 13-24 h in single stables compared with keeping horses on paddocks leads to more activity (trot, canter and passage) during an emotionality reaction test [38]. Several years before, Christensen et al. [39] reported similar findings from a study on stallions. Compared with group-housed stallions, single-housed stallions engaged in more social grooming and more play behavior when being allowed to freely interact with other stallions on pasture after a period of confinement. An accumulated needs-fulfilment deficit leads to a "rebound effect" in horses, as shown in studies examining feed intake [40], resting [41], and locomotion in horses [42,43]. Because locomotion is always associated with stimuli (such as foraging underneath the fence or moving to conspecifics), horses on larger paddocks ( $150 \mathrm{~m}^{2}$ vs. $300 \mathrm{~m}^{2}$ vs. $\left.450 \mathrm{~m}^{2}\right)$ or turned out paired compared to solitary release showed more activity $[44,45]$.

Brain analyses via electroencephalograms, assessment of intestinal microbiota composition, and behavior measurements revealed a positive influence of keeping horses at pasture on the physical and mental wellbeing, as opposed to single housing systems without pasture access $[7,46]$. These results seen in horses kept in confinement suggest that welfare may be compromised when horses are not provided with access to pasture. Therefore, the "Guidelines for Good Animal Welfare Practice for the Keeping of Horses" [47] propose daily turnout for horses independently of additional work or training activities.

\subsection{Aim of the Work}

We herein examine to what extent species-appropriate free-range locomotion possibilities (turnout type and duration) are implemented on horse farms in Germany and to what extent turnout areas are affected by unwanted nutrient inputs from horse excretions. The ultimate goal is to improve horse welfare and the environmental sustainability status of horse husbandry by providing a consulting tool ("BestTUPferd") and thus contribute to a resource-conserving and responsible handling of natural resources and living beings according to the 2030 Agenda for Sustainable Development of the United Nations [11].

\section{Materials and Methods}

\subsection{Data Collection}

From 2013 until 2021, our research project team at the Technical University of MunichWeihenstephan has been developing an on-farm assessment system to evaluate animal welfare and environmental sustainability in horse husbandry. Welfare and environmental sustainability criteria were formulated to address the four principles "behavior indicating positive affective states," "good health status," "horse-appropriate housing conditions," and "environmentally sustainable horse husbandry." This study presents results for two indicators, "species appropriate turnout" and "nitrogen surplus", which were developed and tested on 44 farms (20 farms with group housing and 24 farms with single housing) during the project (Table 1). Single housing was defined as housing systems with horses housed in single boxes and group housing was defined as housing systems with horses live at least with one other horse in a loose housing system (barn with permanent access to a turnout area). We addressed different aspects of the project in four separate trials. Each trial consists of farm visits (one farm visit per day) with the same procedure of data assessment but a different aim regarding the assessment of repeatability (test-retest reliability) and test-retest reliability of the indicators for horse welfare and environmental sustainability. However, the reliability aspects are not addressed in the present study. Trial 3 with two farms was incomplete regarding the information for the calculation of nitrogen surplus. Hence, trial 3 is excluded in the herein presented results. Trial 4 included the test series on the assessment of the digital analysis software. All farms are currently in operation; they include farms that house sport horses or leisure horses or both. The horse farm managers were personally contacted and voluntarily participated in the data collections and assessments; thus, a bias toward farms with good practice cannot be excluded. 
Table 1. Test series within the framework of the development of the digital decision support system for horse husbandry.

\begin{tabular}{cccccc}
\hline Trial & Farms $(\boldsymbol{n})^{\mathbf{1}}$ & Replicates $(\boldsymbol{n})$ & Horses $(\boldsymbol{n})$ & Assessors $(\boldsymbol{n})$ & $\begin{array}{c}\text { Assessments in } \\
\text { Total }(\boldsymbol{n})\end{array}$ \\
\hline 1 & $12(6 \mathrm{G}+6 \mathrm{~S})$ & 4 & 685 & 3 & 48 \\
2 & $18(9 \mathrm{G}+9 \mathrm{~S})$ & 1 & 887 & 1 & 18 \\
3 & $2(1 \mathrm{G}+1 \mathrm{~S})$ & 4 & 32 & 1 & 8 \\
4 & $14(5 \mathrm{G}+9 \mathrm{~S})$ & 1 & 616 & 1 & 14 \\
Sum & $46(21 \mathrm{G}+25 \mathrm{~S})$ & $1-4$ & 2220 & $1-3$ & 88 \\
\hline
\end{tabular}

${ }^{1} \mathrm{G}=$ group housing, $\mathrm{S}=$ single housing.

\subsection{Assessment of Turnout}

The welfare criterion "species-appropriate free-range locomotion possibility" associated with the welfare principle "horse-appropriate housing conditions" was assessed, inter alia, through the daily duration of turnout. Further indicators of this criterion were: "size of turnout," "long side of turnout," "waterlogging on turnout," "morass on turnout," "pavement requirements," "condition of hooves," "turnout as a service offer," "type of turnout in winter and summer," "frequency of turnout per year according to weather," "days per year without turnout due to weather," "frequency of turnout per week," "amount of horses with turnout in winter and summer," "signs of turnout use," and "transfer to turnout by horse farm manager or horse owner."

For an area to be considered as turnout area, it had to meet the size requirement of at least $150 \mathrm{~m}^{2}$ for one or two horses plus $40 \mathrm{~m}^{2}$ for each additional horse [47]. With the exception of one farm ( $n=1$ of 20 farms), all group-housed horses were provided turnout on areas that met the size requirement of the Guidelines for Good Animal Welfare Practice for the Keeping of Horses [47]. One group housing system did not meet this requirement, so every other day, the personnel brought the horses to separate turnout areas. We asked the horse farm managers about the available pasture area per season (winter, summer) and calculated the average pasture area per farm in hectares and the average space allowance in hectares per horse.

\subsection{Calculation of Nitrogen Surplus}

We calculated nitrogen surplus, associated with the above mentioned principle "environmentally sustainable horse husbandry," according to the formula system of Buchgraber et al. $[15,16]$ as shown in Equations (1)-(3) and Table 2.

Nitrogen $(N)$ input (N excretion by the animals): $H_{N} * D_{W / S} * N_{E} * A_{F} * D_{F}$

$$
\begin{gathered}
\text { N output: }-\left(\mathrm{S}_{\mathrm{F}}+\mathrm{H}_{\mathrm{P}}\right) \\
\mathrm{N} \text { surplus (N loss potential })=\mathrm{N} \text { input }-\mathrm{N} \text { output }
\end{gathered}
$$

Table 2. Description of formula symbols and collected data on the farms for the calculation of nitrogen surplus $[12,15,16]$.

\begin{tabular}{cl}
\hline Symbol & \multicolumn{1}{c}{ Description } \\
\hline $\mathrm{H}_{\mathrm{N}}$ & Number of horses \\
$\mathrm{D}_{\mathrm{W} / \mathrm{S}}$ & Days per year on summer (S) or winter $(\mathrm{W})$ turnout area \\
$\mathrm{N}_{\mathrm{E}}$ & Nitrogen (N) excretions in grams per horse and day (values Table 3) \\
$\mathrm{A}_{\mathrm{F}}$ & Area factor calculated by 1/ha of the available turnout area \\
& Demanuring factor: \\
$\mathrm{D}_{\mathrm{F}}$ & 0.1 for daily demanuring (equivalent to $90 \% \mathrm{~N}$ output) \\
& 0.3 for weekly demanuring (equivalent to 70\% N output) \\
$\mathrm{S}_{\mathrm{F}}$ & Sowing factor (seeding pastures afterperiods of turnout which leads to N output \\
$\mathrm{H}_{\mathrm{P}}$ & from the soil into the gras): 38 kg N per hectare \\
& N output for additional hay production on turnout area: $77 \mathrm{~kg}$ N per hectare \\
\hline
\end{tabular}


Table 3. Values for nitrogen excretions depending on type and duration of turnout according to the literature $[12,15,16]$.

\begin{tabular}{|c|c|}
\hline Type and Daily Duration of Turnout & $\begin{array}{c}\text { Nitrogen Excretions } \\
\text { (Feces + Urine) in Grams per } \\
\text { Horse and Day }\end{array}$ \\
\hline Pasture (separate) ${ }^{1}$ for $2 \mathrm{~h}$ & 7.2 \\
\hline Pasture (separate) ${ }^{1}$ for $3 \mathrm{~h}$ & 10.8 \\
\hline Pasture (separate) ${ }^{1}$ for $4 \mathrm{~h}$ & 14.4 \\
\hline Pasture (separate) ${ }^{1}$ for $5 \mathrm{~h}$ & 19.2 \\
\hline Pasture (separate) ${ }^{1}$ for $6-24 \mathrm{~h}$ & 24.0 \\
\hline Free-range stable all day ${ }^{2}$ & 7.1 \\
\hline Mud paddock (separate) ${ }^{3}$, several hours (not specified) & 7.2 \\
\hline
\end{tabular}

${ }_{1}^{1}$ turnout on pasture for several hours independent of housing system (individually or in a group); ${ }^{2}$ horses are living in a loose housing system for $24 / 7$ with a barn and access to a paddock with sealed or unsealed surface (but no integrated pasture); ${ }^{3}$ turnout on grass-free unsealed surface independent of housing system.

The nitrogen excretions that horses release during turnout are influenced by the turnout duration. The effects of the nitrogen excretions, in turn, are influenced by the presence of grass swards and thus by the type or condition of the turnout area. Therefore, according to Buchgraber et al. [15], different values are found depending on the duration and type of turnout (Table 3). It should be noticed that agricultural nitrogen surplus is calculated per year [22]. In Central European climate conditions, horses in winter usually do not have access to the same areas as in summer [48], so that the grass sward on pastures remains protected from damage during the cold season. Therefore, we separately calculated nitrogen surplus per time of year. The grazing season usually begins in spring and ends in fall (May to October) [10]. On most farms, horse farm managers decided to protect the turnout areas with grass growth (pastures) from weather-related grass sward damage in the cold season (wintertime). Therefore, only $11.4 \%$ of the farms (see Section 3.1. Turnout) provided pasture not only in summer but also in winter, supporting the need for differentiated area-based calculations of nitrogen surplus on turnout areas of horse farms. Furthermore, the animal density can vary between summertime and wintertime, and thus the calculation per time of year provides more precise information than the undifferentiated calculation for the whole year. According to the relevant literature and in agreement with the expert advisory board of the project, we set three different categories of nitrogen surplus. The target value was set to maximal $20 \mathrm{~kg}$ nitrogen surplus per hectare and the upper threshold to $50 \mathrm{~kg}$ nitrogen surplus per hectare.

\subsection{Statistical Analysis}

The data for the presented indicators were collected descriptively, qualitatively, or quantitatively by inspecting the housing conditions and interviewing the farm managers. Descriptive statistics were expressed as mean, standard error of the mean, median, minimum, and maximum. Tables and graphs were created in Microsoft Excel 2016. Depending on the data type, the following tests were used for statistical analysis in R (RStudio version 1.1.456 [49]). We performed the statistical analysis using Wilcoxon Rank Sum Test and Linear Regression Models (LM). Wilcoxon Rank Sum Tests (Wilcox.test) were performed to investigate the effect of: season on the space allowance per horse; season (summer, winter) on the nitrogen surplus; housing system (group housing or single housing) on nitrogen surplus, demanuring, sowing, and hay production on the nitrogen surplus by excluding specific treatments and comparing the true data with the data excluding the treatments. We graphically detected $200 \mathrm{~m}^{2}$ as a potential cut-off point by correlating the nitrogen surplus with space allowance per horse. Linear regression models (LM) were additionally used to investigate the effect of housing system on the nitrogen surplus corrected by the factor "space allowance per horse." Although the effect "space allowance per horse" is included in the formula by the area factor and the number of horses we decided to demonstrate the potential crucial influence of space allowance on the nitrogen surplus when compar- 
ing single and group housing using LM (corrected model including the variable "space allowance"). Another LM was used for the influence of space allowance of more or less than $200 \mathrm{~m}^{2}$ on the nitrogen surplus (independent variable) with the season (summer, winter) as an additional dependent (explanatory) variable. All models were run for each question separately.

Differences in the number of farms of the indicator "nitrogen surplus" per category (good, moderate, poor; Table 4) were analyzed with Pearson's chi-squared tests. The significance level was set at 0.05 .

Table 4. Descriptive statistics of nitrogen surplus $(\mathrm{kg} / \mathrm{ha})$ per explanatory variable $(n=44$ farms each with one calculated nitrogen surplus value per time of year).

\begin{tabular}{ccccccc}
\hline $\begin{array}{c}\text { Descriptive } \\
\text { Value }\end{array}$ & Summer & Winter & $\begin{array}{c}\text { Group } \\
\text { Housing }\end{array}$ & $\begin{array}{c}\text { Single } \\
\text { Housing }\end{array}$ & $\begin{array}{c}\text { Space Allowance } \\
<\mathbf{2 0 0} \mathbf{~ m}^{\mathbf{2}}\end{array}$ & $\begin{array}{c}\text { Space Allowance } \\
\mathbf{2 0 0} \mathbf{~ m}^{\mathbf{2}}\end{array}$ \\
\hline Mean & -14.81 & 31.22 & -5.30 & 19.46 & 50.59 & -7.69 \\
Median & -4.24 & 12.01 & 5.35 & 11.25 & 15.71 & 5.08 \\
Minimum & -109.27 & -35.19 & -109.27 & -102.08 & 3.65 & -109.27 \\
Maximum & 58.97 & 468.00 & 79.06 & 468.00 & 468.00 & 58.97 \\
\hline
\end{tabular}

\subsection{Ethics Statement}

Horse farm managers voluntarily participated in the study and were only interviewed about data concerning the management of the horses. This study was non-invasive. No specific treatments or interventions were applied on the animals. The study complies with the Guidelines for Ethical Treatment of Animals in Applied Animal Behavior and Welfare Research (ISAE Ethics Committee, 2017).

\section{Results}

\subsection{Turnout}

In summer, the horses of all farms had access to pasture, regardless of the housing system. In winter, only $11.4 \%$ of the farms $(n=5)$ provided their pasture areas for turnout. Figure $1 \mathrm{a}$ illustrates the daily duration of turnout according to the housing system in winter. Due to the integrated turnout areas with permanent ( $24 \mathrm{~h}$ a day, 7 days a week) possibility for free locomotion in the farms with group housing (free-range stables) almost all grouphoused horses offered turnout for $24 \mathrm{~h}$ /day (95.0\%, $n=19$ farms with group-housed horses versus $0 \%$ of 24 farms with single-housed horses). In the single housing systems, the daily turnout duration on $41.7 \%$ of the farms $(n=10$ farms) was restricted to maximal $4 \mathrm{~h} /$ day (Figure 1a). On $41.7 \%$ of the farms with single housing ( $n=10$ farms), some of the horses were provided no turnout at all or at least no regular turnout in winter $(24.1 \pm 20.4 \%$, median: $12.5 \%$, minimum: 5.6\%, maximum: $63.0 \%$; Figure $1 \mathrm{~b}$ ).

\subsection{Nitrogen Surplus}

The nitrogen surplus, across all housing systems differed considerably between summer and winter on the 44 farms (Trials 1, 2, and 4; Wilcox.test: $p<0.001$; Figure 2a, descriptive statistics Table 4). The number of horses per farm provided with turnout varied little with $47 \pm 27$ horses in summer and $44 \pm 26$ horses in winter (non-significant with $p=0.606$ ). Besides the management-based nitrogen output (through demanuring, etc.), the factor with greatest influence on nitrogen surplus was the turnout area of the farm per time of year. In summer, the average available pasture area per farm (all 44 farms provided pasture in summer) was $7.43 \pm 4.29$ ha (median: 7.00, minimum: 1.40 , maximum: 20.00 ha). In winter, the horses had access to considerably smaller paddock or pasture areas (Wilcox.test: $p<0.001$; summertime: $0.18 \pm 0.12$, median: 0.15, minimum: 0.04, maximum: 0.64 versus wintertime: $0.05 \pm 0.07$, median: 0.02 , minimum: 0.001 , maximum: 0.25 hectares per horse). 
a

Daily duration of turnout on paddock and/or pasture per housing system in winter

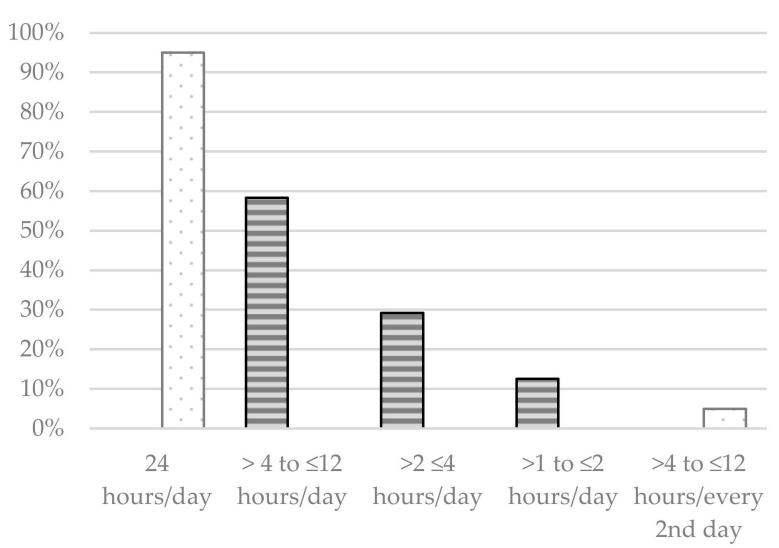

$\boxminus$ Single housing $\square$ Group housing b Single housing systems

(41.7\%) without turnout possibility for all horses

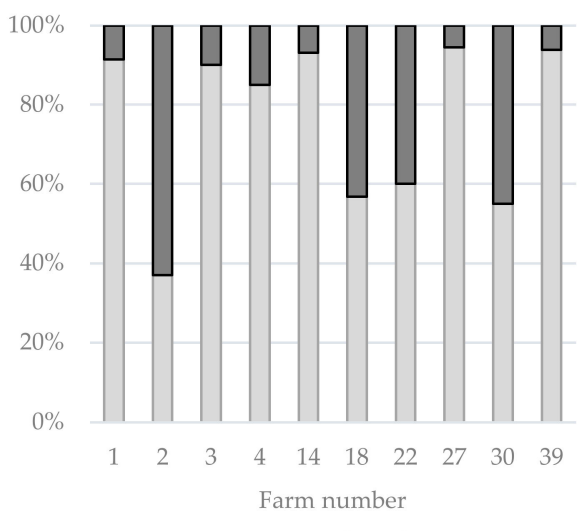

Horses confined

$\square$ Horses with turnout

Figure 1. (a) Daily duration of turnout displayed as hours per day according to housing system ( $n=24$ single housing systems, $n=20$ group housing systems) in winter (November to April); (b) proportion of horses with regard to turnout possibility in winter on each of the 10 farms with single housing systems providing no turnout at all or at least no regular turnout $(41.7 \%, 24.1 \pm 20.4 \%$ of horses per farm, median: $12.5 \%$, minimum: $5.6 \%$, maximum: $63.0 \%$ ).


Figure 2. Nitrogen surplus (a) per time of year ( $n=44$ farms, each with one calculated nitrogen surplus value per time of year; $p<0.001)$ and $(b)$ per space allowance $(n=44$ farms, $p<0.001$; presented in boxplots: box = interquartile range (IQR) from 25th percentile $(\mathrm{Q} 1)$ to 75 th percentile $(\mathrm{Q} 3)$, line inside $\mathrm{IQR}=$ median, cross = mean, minimum whisker $=\mathrm{Q} 1-1.5$ ${ }^{*} \mathrm{IQR}$, maximum whisker $=\mathrm{Q} 3+1.5 * \mathrm{IQR}$, circles = outliers).

Although the values calculated per housing system (single or group housing) suggested a higher nitrogen surplus for single housing systems compared with group housing systems and the Wilcoxon Rank Sum Test confirms that (Wilcox.test: $p=0.035$ ), the difference was not statistically supported when space allowance was taken into account (LM: $\mathrm{df}=85$, regression coefficient for housing system $=-19.22, p=0.12$, regression coefficient for space allowance $-239.87, p<0.001$, whole model: $p<0.001$, descriptive 
statistics Table 4). The graphically detected cut-off-point of $200 \mathrm{~m}^{2}$ space allowance per horse influenced the nitrogen surplus even if corrected for season (LM: $\mathrm{df}=85$, regression coefficient for $200 \mathrm{~m}^{2}$ space allowance $=-21.30, p=0.02$, regression coefficient for season 22.80, $p=0.15$, whole model: $p<0.001$, Figure $2 b$, descriptive statistics Table 4).

Because all farms provided pasture areas as turnout for the horses in summer, we found with one exception (Farm 25 with $58.97 \mathrm{~kg}$ nitrogen surplus per hectare) no exceedance of the nitrogen surplus threshold (Figure 3a). Farm 3 was an extreme outlier regarding nitrogen surplus in the wintertime with $468 \mathrm{~kg} / \mathrm{ha}$ (Figure 3b). In this farm, the pasture area available for turnout in winter was only 0.4 ha for 100 horses (space allowance: $40 \mathrm{~m}^{2}$ per horse).
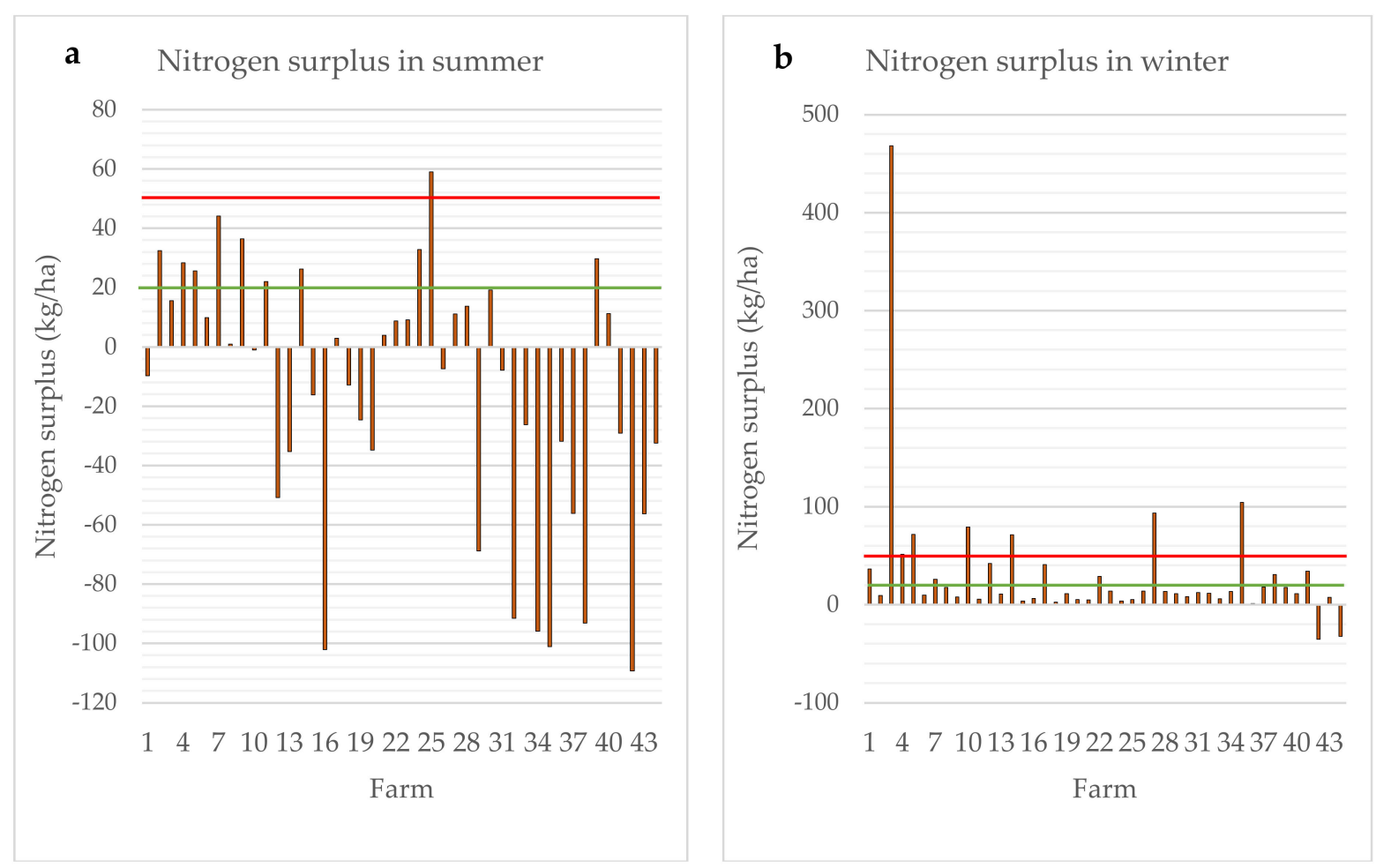

Figure 3. Nitrogen surplus per farm ( $n=44$ farms) (a) in summer and (b) in winter; green line: target value $\leq 20 \mathrm{~kg}$ nitrogen surplus per hectare, red line: upper threshold $\geq 50 \mathrm{~kg}$ nitrogen surplus per hectare.

The nitrogen surplus target value of $20 \mathrm{~kg} /$ ha was exceeded on $29.5 \%$ ( $n=13$ of 44$)$ of the farms in summer and on $31.8 \%$ ( $n=14$ of 44$)$ of the farms in winter (Figure 3$)$. The nitrogen surplus upper threshold of $50 \mathrm{~kg} / \mathrm{ha}$ was exceeded on $15.9 \%(n=7$ of 44$)$ of the farms in winter (Figure 3b; Table 4$)$. In summer, three farms $(6.8 \% ; n=3$ of 44 farms) exceeded the upper threshold (Figure 3a; Table 5). However, the differences in the number of farms per category of nitrogen surplus in dependence of the season are non-significant (Pearson's chi-squared test: $\chi 2=3 ; \mathrm{df}=2 ; p=0.22$ ).

Table 5. Number of farms $(n=44)$ according to category of nitrogen surplus and to the time of year (differences non-significant).

\begin{tabular}{cccc}
\hline Time of Year & $\begin{array}{c}\text { Good: } \\
\mathbf{2 0} \mathbf{~ k g}\end{array}$ & $\begin{array}{c}\text { Moderate: } \\
\mathbf{2 0} \mathbf{~ k g} \text { to }<\mathbf{5 0 ~} \mathbf{~ k g}\end{array}$ & $\begin{array}{c}\text { Poor: } \\
\mathbf{5 0 0} \mathbf{~ k g}\end{array}$ \\
\hline summertime & 31 & 10 & 3 \\
wintertime & 30 & 7 & 7 \\
\hline
\end{tabular}

We found out that specific treatments that are variables of the formula for calculating the nitrogen surplus influence the nitrogen surplus differently. This was done by relating 
the true data with the data excluding the treatments. Whereas the output of hay production (Wilcox.test: non-significant with $p=0.27$ ), and the output for sowing (Wilcox.test: nonsignificant with $p=0.08$ ) do not have a remarkable impact on the nitrogen surplus in the presented data, demanuring significantly influenced the nitrogen surplus (Wilcox.test: $p<0.001$, descriptive statistics Table 6, Figure 4).

Table 6. Descriptive statistics of nitrogen surplus $(\mathrm{kg} / \mathrm{ha}$ ) without specific treatments $(n=44$ farms each with one calculated nitrogen surplus value per time of year).

\begin{tabular}{ccccc}
\hline $\begin{array}{c}\text { Descriptive } \\
\text { Value }\end{array}$ & $\begin{array}{c}\text { Calculated } \\
\text { Nitrogen } \\
\text { Surplus }\end{array}$ & $\begin{array}{c}\text { Nitrogen } \\
\text { Surplus } \\
\text { without } \\
\text { Demanuring }\end{array}$ & $\begin{array}{c}\text { Nitrogen Surplus } \\
\text { without Output } \\
\text { for Hay } \\
\text { Production }\end{array}$ & $\begin{array}{c}\text { Nitrogen } \\
\text { Surplus } \\
\text { without Output } \\
\text { for Sowing }\end{array}$ \\
\hline Mean & 8.20 & 60.35 & 17.65 & 19.09 \\
Median & 9.70 & 28.60 & 11.16 & 12.05 \\
Minimum & -109.27 & -109.27 & -35.27 & -71.27 \\
Maximum & 468.00 & 1045.16 & 468.00 & 468.00 \\
\hline
\end{tabular}



Figure 4. Comparison of nitrogen surplus ( $n=44$ farms) of the true calculated nitrogen surplus data with the same data excluding different specific treatments (comparison of nitrogen surplus with nitrogen surplus without demanuring: $p<0.001$; comparison of nitrogen surplus with nitrogen surplus without output for hay production: non-significant with $p=0.27$; comparison of nitrogen surplus with nitrogen surplus without output for sowing: non-significant with $p=0.08$; presented in boxplots: box = interquartile range (IQR) from 25th percentile (Q1) to 75th percentile (Q3), line inside $\mathrm{IQR}=$ median, cross = mean, minimum whisker $=\mathrm{Q} 1-1.5{ }^{*} \mathrm{IQR}$, maximum whisker $=\mathrm{Q} 3+$ $1.5{ }^{*} \mathrm{IQR}$, circles = outliers).

\section{Discussion}

A sustainable approach needs not only global but also regional action [50]. In Germany, horse husbandry, including horse breeding, is of high national and international significance [17]. On the one hand, horses play an increasingly important role as grazer species in European managed grasslands [48,51], they are of socioeconomic significance (important economic sector with high recreational value) [52], and they provide ecological benefits [10]. On the other hand, especially peri-urban horse farms are prone to an elevated risk of unwanted nutrient inputs because the pasture space allowance is often limited $[13,14]$. For horse husbandry to be socially accepted and sustainable, it must consider aspects of both animal welfare and environmental sustainability. Combining animal 
welfare with ecological aspects of the sustainability concept has been neglected so far and should support the implementation of a One Health, One Welfare approach $[25,53]$. The goals of the United Nations for sustainable development envisage the protection of natural resources and living beings [11] and thus are supported by presented indicators of animal welfare and environmental sustainability. These indicators will support horse farm managers to act more sustainably and in a welfare-friendly manner by helping them decide how to improve their horse husbandry rather than telling them what to do [54].

\subsection{Turnout}

According to the Guidelines for Good Animal Welfare Practice for the Keeping of Horses [47], controlled exercise (i.e., work, training) does not include the same movement sequences as free locomotion during turnout does, during which locomotion in relaxed walking pace predominates but excess energy and tension can be released as well. Controlled exercise can therefore be offered in addition to turnout but cannot replace it under any circumstance. Thus, in view of animal welfare, restricting or omitting the daily turnout for horses is no option. Our assessment showed that especially the group housing systems offered species-appropriate turnout possibilities and in this regard provided horseappropriate housing conditions. In $95 \%$ of the farms with group housing, we recorded a directly adjacent or integrated turnout area that was large enough and suitable for gallop. Such turnout areas give the horses the permanent ( $24 \mathrm{~h}$ a day, 7 days a week) choice for free locomotion and even provide stimuli for locomotion. In contrast, single-housed horses depend on an intensive turnout management by the horse farm manager because they need to be brought to turnout areas and returned to the stable daily. The majority (58\%) of the herein assessed farms with single housing systems provided daily turnout for more than $4 \mathrm{~h}$ in summer and in winter. Regarding animal welfare, several hours of daily free locomotion to compensate for the activity deficit in single housing can be rated as positive. However, the data collection so far cannot be considered representative for Germany or Central Europe because the voluntary participation in our study likely caused a bias toward farms with above-average good welfare management. Therefore, we cannot rule out that horses in Germany experience limited possibilities for free locomotion, especially in winter.

Our data furthermore show that in winter, a large share of the farms with single housing (approx. $42 \%$ ) did not provide turnout for all horses (range of horses confined per farm: 6-63\%). This finding confirms the results of a previous study, in which participants of a survey stated that several of the housed horses $(9-12 \%)$ were not provided additional turnout [17]. This situation is a violation of the German Animal Welfare Act, which stipulates the welfare of each individual animal [55]. According to $\S 2$ of the German Animal Welfare Act, a housing system must not restrict the possibility for species-appropriate locomotion in a way that inflicts pain, avoidable suffering, or harm on the animal [55]. Depending on the type, extent, and duration of a restriction, animals suffer when their needs are not met and they experience the situation as uncontrollable [56]. Lacking or irregular turnout for individuals among the housed animals can lead to a built-up urge to move with rebound effects in these animals, increasing the risk for injuries and for the development of stereotypies $[6,39,42,43]$. There is enough scientific evidence today that stereotypic behavior is an indicator of acute or past suffering in animals [57]. Because $88.6 \%$ of the farms did not provide access to pasture in winter, stereotypic behavior on these farms could be prevented most effectively by the combined provision of free-choice hay and turnout [58]. In summary, lack of free locomotion can cause suffering and thus must be considered inacceptable $[55,56]$.

\subsection{Nitrogen Surplus and the Linkage to "Turnout"}

We selected nitrogen surplus as an indicator of the sustainability criterion "surface and ground water protection" for the principle "environmentally sustainable horse husbandry." The results indicated a need for fertilization in summer because the average nitrogen surplus was negative on $54.5 \%$ of the farms and thus the majority. As part of an examination 
regarding proper pasture management, we found that the need for fertilizing the pasture areas was addressed on all farms. However, details are not presented in this article. In winter, nitrogen surplus was considerably higher and, considering the health hazards of nitrate in drinking water, above threshold [19].

The present study showed a markedly reduced space allowance on pasture for the horses in winter $(1.82 \pm 2.85$ ha per farm) as compared with summer $(7.43 \pm 4.29$ ha per farm). Restrictions in pasture access bear additional negative effects in the form of rebound behaviors. For example, Schmitz et al. [59] found that horses increase running and trampling on pasture with decreasing grazing duration. Consequently, the stress on grass swards increases and poses a challenge to sustainable grassland management. Thus, the best measure for improvement is providing large pasture areas because they offer not only locomotion stimuli but also enough space to reduce horse-based stress on grass swards and nitrogen inputs per hectare. The larger the pasture, the longer the horses can be allowed to graze- -because according to literature the longer the grazing duration, the less likely horses show a rebound effect in their locomotion behavior with intense running and trampling. Therefore, providing large enough pasture areas year-round can entail various synergetic effects for environmental sustainability and animal welfare.

We found tendentially higher nitrogen surpluses on turnout areas of single-housed horses compared with turnout areas of group-housed horses, suggesting that group housing of horses may support a better paddock and pasture management due to the generally integrated turnout areas (e.g., daily demanuring) and thereby reduce excretions of the horses in the soil. Schmitz and Isselstein [59] also pointed out the potential of free-range stabling (i.e., active stables, paddock trails), as opposed to box-stall stabling, to enable sustainable grazing management. However, when the space allowance per horse is taken into account, the effect of housing system vanishes. Therefore, our study confirms the strong effect of the space allowance rather than recommends one housing system over the other in terms of nitrogen surplus.

A factor with strong influence on problematic nitrogen inputs in the calculation following Buchgraber et al. $[15,16]$ is the space allowance per horse. If many horses graze daily on a relatively small area, problems with excessive nitrogen surplus will inevitably arise. Although many factors are included in the calculation of nitrogen surplus, our results show that a space allowance of less than 0.02 ha per horse ( $200 \mathrm{~m}^{2}$ per horse) for several hours of turnout can only be compensated with daily demanuring or with sowing of the pasture after the winter grazing period (or both)—because demanuring reduces nitrogen inputs by $90 \%$ and sowing reduces nitrogen surplus by $38 \mathrm{~kg} / \mathrm{ha}[12,15,16]$. We could demonstrate that the strongest effect of nitrogen reduction is demanuring. The extreme outlier of $468 \mathrm{~kg} \mathrm{~N} /$ ha shows how far it can get when space allowance is very limited (farm 3: $40 \mathrm{~m}^{2}$ per horse) on unsurfaced areas. In addition, the area neither was sowed after usage (end of winter period) nor was it demanured daily or at least once a week. However, the outlier had no great effect on the results, because we performed Wilcoxon Rank Sum Test, which only take the ranks of the results into account.

The calculation of nitrogen surplus according to the method of Buchgraber et al. $[12,15,16]$ includes the benefit that problematic horse turnout management can be identified efficiently by using fixed variables. Thus, it allows pointing out an environmentally relevant and potential health hazardous problem that previously received little attention. However, the formula has shortcomings due to its abstract nature because it contains fixed values for variable amounts. For example, hay production depends on growth performance and thus on biomass production. Therefore, the calculation should be differentiated according to site and management conditions. Furthermore, the method does not take further influencing factors on the nitrogen input into account, e.g., protein content of fodders and utilization. Future studies should address further aspects of nitrogen excretion for a detailed analysis.

A large pasture space allowance not only benefits the horses by allowing peaceful coexistence (less aggression) [60] and providing enough space to satisfy the need for locomotion and permit higher speed while running [59]; it can also contribute considerably to 
reducing the nitrogen surplus. In summary, we could identify measures that enhance both animal welfare and the conservation of resources and thus transform allegedly conflicting goals into a synergetic effect.

\section{Conclusions}

The herein presented results demonstrate how allegedly conflicting goals-providing horses with resources such as pasture space that allows species-appropriate free-range locomotion possibilities on the one hand, preventing unwanted nutrient inputs into the soil on these pastures on the other hand - can be addressed in a way that produces a synergetic effect: enhancing both animal welfare and environmental sustainability. Particularly, the greater the space allowance per horse on pasture is the less the nitrogen surplus added up. Based on the study, we recommend to daily demanure the pasture or paddock if the space allowance is less than $200 \mathrm{~m}^{2}$ per horse.

Furthermore, our study showed that many horse farms in Germany still need optimization concerning animal welfare. To be specific, our study showed that species-appropriate free-range locomotion possibilities is not given for a large share of horses in single housing systems. In contrast, almost all group housing systems offer species-appropriate turnout possibilities. In conclusion, regarding animal welfare, group housing is favorable, but regarding a site-specific environmentally friendly or even biodiversity-enhancing management, space allowance per horse is a crucial factor rather than the type of housing system.

The simultaneous assessment of environmental sustainability and animal welfare in a digital decision support system help people with horses under their care to understand the relationship between equine husbandry practices and nitrogen surplus and to choose recommendations for action.

Author Contributions: Conceptualized the study, M.B.; carried out the practical data collection on farms, M.B. and S.K.; performed the formal and statistical analyses, M.B.; drafted the manuscript, M.B.; revised the paper, M.B., S.K., M.H.E., K.-J.H. and M.H.Z.-F.; acquired funding, M.B. and M.H.Z.-F.; edited the paper, M.B. All authors have read and agreed to the published version of the manuscript.

Funding: This ongoing research project is supported by funds of the German Government's Special Purpose Fund held at Landwirtschaftliche Rentenbank (grant number: 849 485, acronym: BestTUPferd).

Institutional Review Board Statement: Ethical review and approval were waived for this study, due to horse farm managers only being interviewed about data concerning the management of the horses and no treatment or interventions being done on the horses. See also the Ethics Statement in Section 2.5.

Informed Consent Statement: Not applicable.

Data Availability Statement: The data that support the findings of this study are available on request from the corresponding author, [M.B.]. The data are not publicly available due to their containing information that could compromise the privacy of participating horse farm managers.

Acknowledgments: We would like to thank the expert advisory board for many years of intense and constructive discussions within the research project. The experts are namely: Christine Aurich - Vetmed University Vienna; Ute Knierim-University Kassel-Witzenhausen; Henrike Lagershausen-Deutsche Reiterliche Vereinigung (FN) e. V.- and her predecessor Michael Düe; Christiane Müller-Deutsche Reiterliche Vereinigung (FN) e. V.; Sophie Schuster Hankel—LaufstallArbeits-Gemeinschaft für artgerechte Pferdehaltung (LAG) e. V.-and her predecessor Sigrid Koch; Susanne Gäckler-Deutsche Landwirtschafts-Gesellschaft e. V. (DLG); Eberhard Schüle-Gesellschaft für Pferdemedizin (GPM) e. V.; Andreas Franzky—Tierärztliche Vereinigung für Tierschutz e. V. (TVT); Rüdiger Deckert-Röwer \& Rüb GmbH; Thorsten Hinrichs-HIT-Aktivstall GmbH; Anja Dörrzapf-Bundestierärztekammer (BTK) e. V.; Wilken Treu-Hannoveraner Verband; Sker Friedhoff \& Felix Garlipp-Uelzener Allgemeine Versicherungs-Gesellschaft a. G.; Petra Duering-Bayerischer Bauernverband (BBV) e. V.; Heiner Sauter-Vereinigung der Freizeitreiter und -fahrer in Deutschland (VFD) e. V. 
Conflicts of Interest: The authors declare no conflict of interest. The funders had no role in the design of the study; in the collection, analyses, or interpretation of data; in the writing of the manuscript; or in the decision to publish the results.

\section{References}

1. Deutscher Ethikrat. Tierwohlachtung-Zum verantwortlichen Umgang mit Nutztieren. In Stellugnnahme; Deutscher Ethikrat: Berlin, Germany, 2020.

2. FN. Wie pferdegerecht sind Ausbildung, Turniersport und Pferdehaltung in Deutschland? In Online-Umfrage (fn-Press) der Deutschen Reiterlichen Vereinigung e.V. (FN), Warendorf. 2016. Available online: https://www.ipzv.de/newsdetailkurzmeldungen/fn-umfrage-zu-ausbildung-turniersport-und-pferdehaltung.html (accessed on 9 August 2021).

3. Winkel, C.; Schukat, S.; Heise, H. Importance and Feasibility of Animal Welfare Measures from a Consumer Perspective in Germany. Food Ethics 2020, 5, 21. [CrossRef]

4. Horseman, S.V.; Buller, H.; Mullan, S.; Whay, H.R. Current Welfare Problems Facing Horses in Great Britain as Identified by Equine Stakeholders. PLoS ONE 2016, 11, e0160269. [CrossRef] [PubMed]

5. Dalla Costa, E.; Dai, F.; Lebelt, D.; Scholz, P.; Barbieri, S.; Canali, E.; Minero, M. Initial outcomes of a harmonized approach to collect welfare data in sport and leisure horses. Animal 2017, 11, 254-260. [CrossRef]

6. Sarrafchi, A.; Blokhuis, H.J. Equine stereotypic behaviors: Causation, occurrence, and prevention. J. Vet. Behav. 2013, 8, 386-394. [CrossRef]

7. D'Ingeo, S.; Quaranta, A.; Siniscalchi, M.; Stomp, M.; Coste, C.; Bagnard, C.; Hausberger, M.; Cousillas, H. Horses associate individual human voices with the valence of past interactions: A behavioural and electrophysiological study. Sci. Rep. 2019, 9, 11568. [CrossRef] [PubMed]

8. Ruet, A.; Lemarchand, J.; Parias, C.; Mach, N.; Moisan, M.-P.; Foury, A.; Briant, C.; Lansade, L. Housing Horses in Individual Boxes Is a Challenge with Regard to Welfare. Animals 2019, 9, 621. [CrossRef]

9. Hausberger, M.; Lerch, N.; Guilbaud, E.; Stomp, M.; Grandgeorge, M.; Henry, S.; Lesimple, C. On-Farm Welfare Assessment of Horses: The Risks of Putting the Cart before the Horse. Animals 2020, 10, 371. [CrossRef]

10. Schmitz, A.; Isselstein, J. Effect of Grazing System on Grassland Plant Species Richness and Vegetation Characteristics: Comparing Horse and Cattle Grazing. Sustainability 2020, 12, 3300. [CrossRef]

11. United Nations. Tansforming our world: The 2030 Agenda for Sustainable Development. Seventieth session Agenda items 15 and 116. In Proceedings of the 2030 Agenda for Sustainable Development, New York, NY, USA, 25-27 September 2015; pp. 1-35. Available online: https:/ /sdgs.un.org/2030agenda (accessed on 9 August 2021).

12. Buchgraber, K.; Braach, J.; Münsch, C. Stickstoffanfall Bei Pferden Auf Gatschkoppeln und dessen Umweltrelevanz. In Gülle 11-Gülle-und Gärrestdüngung auf Grünland; Elsäßer, M., Diepolder, M., Huguenin-Elie, O., Pötsch, E., Nußbaum, H., Messner, J., Eds.; Kloster Reute, Landwirtschaftliches Zentrum Baden-Württemberg (LAZBW): Württemberg, Germany, 2011.

13. Bomans, K.; Dewaelheyns, V.; Gulinck, H. Pasture for horses: An underestimated land use class in an urbanized and multifunctional area. Int. J. SDP 2011, 6, 195-211. [CrossRef]

14. Zasada, I.; Berges, R.; Hilgendorf, J.; Piorr, A. Horsekeeping and the peri-urban development in the Berlin Metropolitan Region. J. Land Use Sci. 2013, 8, 199-214. [CrossRef]

15. Buchgraber, K.; Braach, J.; Münsch, C.; Erasimus, L.; Feichtinger, F.; Dorner, J.; Konheisner, G. Pferde auf Gatschkoppeln. In Der fortschrittliche Landwirt-Fachzeitschrift für die Bäuerliche Familie-Sonderbeilage Pferd Plus; Stocker-Verlag: Graz, Austria, 2011; pp. $1-12$.

16. Buchgraber, K.; Braach, J.; Münsch, C.; Erasimus, L.; Feichtinger, F.; Dorner, J.; Konheisner, G. Calculations are correct: Successful management coupling reduces the nitrate contamination and protects the groundwater (Richtig gerechnet-Erfolgreiches Koppelmanagement mindert die Nitratbelastung und schützt das Grundwasser). Pferdefokus 2012, 3, 30-34.

17. Hölker, S.; Wiegand, K.; Münch, C.; Spiller, A. Georg-August-Universität Göttingen. Lehrstuhl, Marketing für Lebensmittel und Agrarprodukte. In Pferdehaltung Heute: Eine Strukturdatenerfassung Pferdehaltender Betriebe in Deutschland; HorseFuturePanel UG: Göttingen, Germany, 2017.

18. Council Directive Concerning the Protection of Waters Against Pollution Caused by Nitrates from Agricultural Sources (the Nitrates Directive); EEC: Brussels, Belgium, 1991.

19. Schullehner, J.; Hansen, B.; Thygesen, M.; Pedersen, C.B.; Sigsgaard, T. Nitrate in drinking water and colorectal cancer risk: A nationwide population-based cohort study. Int. J. Cancer 2018, 143, 73-79. [CrossRef]

20. Groundwater Protection in Europe-The New Groundwater Directive-Consolidating the Eu Regulatory Framework: The Groundwater Directive 2006/118/EC; European Commission: Luxembourg, 2008.

21. Richtlinie für die Sachgerechte Düngung im Ackerbau und im Grünland-Anleitung zur Interpretation von Bodenuntersuchungsergebnissen in der Landwirtschaft (SAG), 7th ed.; Bundesministerium für Land- und Forstwirtschaft, Umwelt und Wasserwirtschaft: Vienna, Austria, 2017.

22. Verordnung über die Anwendung von Düngemitteln, Bodenhilfsstoffen, Kultursubstraten und Pflanzenhilfsmitteln nach den Grundsätzen der guten fachlichen Praxis beim Düngen: Düngeverordnung-DüV; Bundesministeriums der Justiz und für Verbraucherschutz: Berlin, Germany, 2017. 
23. Küstermann, B.; Christen, O.; Hülsbergen, K.-J. Modelling nitrogen cycles of farming systems as basis of site-and farm-specific nitrogen management. Agric. Ecosyst. Environ. 2010, 135, 70-80. [CrossRef]

24. Broom, D.M. Indicators of poor welfare. Br. Vet. J. 1986, 142, 524-526. [CrossRef]

25. Tarazona, A.M.; Ceballos, M.C.; Broom, D.M. Human Relationships with Domestic and Other Animals: One Health, One Welfare, One Biology. Animals 2019, 10, 43. [CrossRef]

26. Minero, M.; Dalla Costa, E.; Dai, F. AWIN Welfare Assessment Protocol for Horses; AWIN: Edinburgh, UK, 2015. [CrossRef]

27. Dalla Costa, E.; Murray, L.; Dai, F.; Canali, E.; Minero, M. Equine on-farm welfare assessment: A review of animal-based indicators. Anim. Welf. 2014, 23, 323-341. [CrossRef]

28. Viksten, S.M. Improving Horse Welfare through Assessment and Feedback. Ph.D. Thesis, Swedish University of Agricultural Sciences, Uppsala, Sweden, 2016.

29. Viksten, S.M.; Visser, E.K.; Nyman, S.; Blokhuis, H.J. Developing a horse welfare assessment protocol. Anim. Welf. 2017, 26, 59-65. [CrossRef]

30. Graham-Thiers, P.M.; Bowen, L.K. Improved Ability to Maintain Fitness in Horses During Large Pasture Turnout. J. Equine Vet. Sci. 2013, 33, 581-585. [CrossRef]

31. Safran, M.R.; Garrett, W.E.; Seaber, A.V.; Glisson, R.R.; Ribbeck, B.M. The role of warmup in muscular injury prevention. Am. J. Sports Med. 1988, 16, 123-129. [CrossRef]

32. Wilke, A. Effects of Rearing Conditions and Growth Rates on the Development of Osteochondrosis (OC) in Riding Horses; Tierärztliche Hochschule Hannover: Hannover, Germany, 2003.

33. Gygax, L. Wanting, liking and welfare: The role of affective states in proximate control of behaviour in vertebrates. Ethology 2017, 123, 689-704. [CrossRef]

34. Metz-Göckel, H. "need" (Bedürfnis) in Dorsch Lexikon der Psychologie, 19th ed.; Wirtz, M.A., Ed.; Hogrefe Verlag GmbH \& Co. KG: Göttingen, Germany, 2020. Available online: https:/ / dorsch.hogrefe.com/stichwort/beduerfnis/ (accessed on 10 August 2021).

35. Zeitler-Feicht, M.H. Horse Behaviour Explained: Origins, Treatment and Prevention of Problems, 1st ed.; Manson Publishing: London, UK, 2004.

36. Würbel, H.; Bergeron, R.; Cabib, S. The Coping Hypothesis of Stereotypic Behaviour. In Stereotypic animal behaviour, Fundamentals and Applications to Welfare; Mason, G., Rushen, J., Eds.; CABI Publishing: Wallingford, UK, 2006.

37. Hockenhull, J.; Creighton, E. The day-to-day management of UK leisure horses and the prevalence of owner-reported stablerelated and handling behaviour problems. Anim. Welf. 2015, 24, 29-36. [CrossRef]

38. Lesimple, C.; Fureix, C.; LeScolan, N.; Richard-Yris, M.-A.; Hausberger, M. Housing conditions and breed are associated with emotionality and cognitive abilities in riding school horses. Appl. Anim. Behav. Sci. 2011, 129, 92-99. [CrossRef]

39. Christensen, J.W.; Ladewig, J.; Søndergaard, E.; Malmkvist, J. Effects of individual versus group stabling on social behaviour in domestic stallions. Appl. Anim. Behav. Sci. 2002, 75, 233-248. [CrossRef]

40. Baumgartner, M.; Boisson, T.; Erhard, M.H.; Zeitler-Feicht, M.H. Common Feeding Practices Pose A Risk to the Welfare of Horses When Kept on Non-Edible Bedding. Animals 2020, 10, 411. [CrossRef] [PubMed]

41. Chaplin, S.J.; Gretgrix, L. Effect of housing conditions on activity and lying behaviour of horses. Animal 2010, 4, 792-795. [CrossRef] [PubMed]

42. Chaya, L.; Cowan, E.; McGuire, B. A note on the relationship between time spent in turnout and behaviour during turnout in horses (Equus caballus). Appl. Anim. Behav. Sci. 2006, 98, 155-160. [CrossRef]

43. Freire, R.; Buckley, P.; Cooper, J.J. Effects of different forms of exercise on post inhibitory rebound and unwanted behaviour in stabled horses. Equine Vet. J. 2009, 41, 487-492. [CrossRef]

44. Jørgensen, G.H.M.; Bøe, K.E. A note on the effect of daily exercise and paddock size on the behaviour of domestic horses (Equus caballus). Appl. Anim. Behav. Sci. 2007, 107, 166-173. [CrossRef]

45. Stachurska, A.; Różańska-Boczula, M.; Wnuk-Pawlak, E. The difference in the locomotor activity of horses during solitary and paired release: Unterschiede der lokomotorischen Aktivität von Pferden während des Auslaufs alleine und paarweise. Pferdeheilkunde Equine Med. 2021, 37, 50-55. [CrossRef]

46. Mach, N.; Lansade, L.; Bars-Cortina, D.; Dhorne-Pollet, S.; Foury, A.; Moisan, M.-P.; Ruet, A. Gut microbiota resilience in horse athletes following holidays out to pasture. Sci. Rep. 2021, 11, 5007. [CrossRef]

47. GFFA. Guidelines for Good Animal Welfare Practice for the Keeping of Horses (Leitlinien zur Beurteilung von Pferdehaltungen unter Tierschutzgesichtspunkten), 2nd ed.; German Federal Ministry of Food and Agriculture (Bundesministerium für Ernährung und Landwirtschaft): Berlin, Germany, 2009.

48. Schmitz, A.; Isselstein, J. Wieviel Grünland wird in Deutschland für Pferde genutzt? Versuch einer Quantifizierung anhand von Bestands- und Praxisdaten. In Berichte über Landwirtschaft-Zeitschrift für Agrarpolitik und Landwirtschaft; German Federal Ministry of Food and Agriculture (Bundesministerium für Ernährung und Landwirtschaft): Berlin, Germany, 2018.

49. RStudio Team. RStudio: Integrated Development for R; RStudio, PBC: Boston, MA, USA, 2020. Available online: http://www. rstudio.com/ (accessed on 10 August 2021).

50. Siebrecht, N. Sustainable Agriculture and Its Implementation Gap-Overcoming Obstacles to Implementation. Sustainability 2020, 12, 3853. [CrossRef]

51. Jouven, M.; Vial, C.; Fleurance, G. Horses and rangelands: Perspectives in Europe based on a French case study. Grass Forage. Sci. 2016, 71, 178-194. [CrossRef] 
52. FN. Zahlen \& Fakten aus Pferdesport und Pferdezucht: Wirtschaftsfaktor Pferd. Available online: https://www.pferd-aktuell. de/deutsche-reiterliche-vereinigung/zahlen--fakten (accessed on 10 August 2021).

53. Eisler, M.C.; Lee, M.R.F.; Tarlton, J.F.; Martin, G.B.; Beddington, J.; Dungait, J.A.J.; Greathead, H.; Liu, J.; Mathew, S.; Miller, H.; et al. Agriculture: Steps to sustainable livestock. Nature 2014, 507, 32-34. [CrossRef]

54. Kroebel, R.; Stephens, E.; Gorzelak, M.; Thivierge, M.-N.; Akhter, F.; Nyiraneza, J.; Singer, S.; Geddes, C.M.; Glenn, A.; Devillers, N.; et al. Making farming more sustainable by helping farmers to decide rather than telling them what to do. Environ. Res. Lett. 2021, 16, 055033. [CrossRef]

55. TierSchG: Tierschutzgesetz in der Fassung der Bekanntmachung Vom 18. Mai 2006 (BGBl. I S. 1206, 1313), zuletzt durch Artikel 1 des Gesetzes vom 18. Juni 2021 (BGBl. I S. 1828) Geändert; Bundesministeriums der Justiz und für Verbraucherschutz: Berlin, Germany, 2021.

56. Tierschutzgesetz Kommentar: Mit TierSchHundeV, TierSchNutztV, TierSchVersV, TierSchTrV, EU-Tiertransport-VO, TierSchlV, EUTierschlacht-VO; Auflage, H.A.; Maisack, C.; Moritz, J. (Eds.) Vahlen, Franz: München, Germany, 2016; ISBN 9783800662388.

57. Düpjan, S.; Puppe, B. Abnormal behaviour with a focus on stereotypies-indicators of suffering and impaired welfare? (Abnormales Verhalten mit dem Schwerpunkt Stereotypien-Indikator für Leiden und beeinträchtigtes Wohlbefinden?). KG Berl Münch Tierärztl Wochenschr 2016, 93-102. [CrossRef]

58. Henderson, A.J.Z. Don't fence me in: Managing psychological well being for elite performance horses. J. Appl. Anim. Welf. Sci. 2007, 10, 309-329. [CrossRef] [PubMed]

59. Schmitz, A.; Tonn, B.; Schöppner, A.-K.; Isselstein, J. Using a Citizen Science Approach with German Horse Owners to Study the Locomotion Behaviour of Horses on Pasture. Sustainability 2020, 12, 1835. [CrossRef]

60. Flauger, B.; Krueger, K. Aggression level and enclosure size in horses (Equus caballus). Pferdeheilkunde Equine Med. 2013, 29, 495-504. [CrossRef] 